\title{
PRAWO ALIMENTACYJNE SENIORÓW NA GRUNCIE KODEKSU RODZINNEGO I OPIEKUŃCZEGO ORAZ ORZECZNICTWA SĄDOWEGO
}

\begin{abstract}
Streszczenie
Z uwagi na fakt, że tematyka związana z problemem starzenia się społeczeństw jest coraz częściej obecna $w$ dyskursie publicznym, pojawiaja się pytania dotyczace osób starszych. Padają one $w$ różnym kontekście, natomiast za bezsporna kwestię należy uznać, iż seniorzy czesto ze względu na swój zaawansowany wiek, czy też problemy zdrowotne potrzebuja pomocy materialnej. Co prawda państwo dysponuje odpowiednimi instrumentami pomocowymi, które sa adresowane dla takiej grupy adresatów, to jednak należy podkreślić, że obowiązek alimentacyjny rodziny powinien być realizowany $w$ pierwszej kolejności. Dlatego też problematyka obowiąku alimentacyjnego względem osób starszych została podjęta w niniejszym tekście, gdyż skupia się na obowiazkach wynikajacych z rodzinnej więzi. Analiza zagadnienia została omówiona na przykładzie orzecznictwa sądów powszechnych oraz Sądu Najwyższego, a także na podstawie zapisów Kodeksu Rodzinnego i Opiekuńczego.
\end{abstract}

Słowa kluczowe: senior, osoba starsza, alimenty, obowiazek alimentacyjny, Kodeks Rodzinny i Opiekuńczy, orzecznictwo.

* Piotr Czekalski - absolwent Wydziału Prawa i Administracji Uniwersytetu Kardynała Stefana Wyszyńskiego w Warszawie. 


\section{Wprowadzenie}

W dzisiejszych czasach możemy dostrzec coraz większy odsetek osób starszych i to zarówno w Polsce, jak i w innych krajach europejskich. Fakt ten wynika z procesu starzenia się społeczeństw, który przejawia się w różnym nasileniu, nie mniej jest on związany z zaistnieniem dwóch okoliczności. $Z$ jednej strony jest to wydłużenie średniej długości trwania życia i spadku umieralności, a z drugiej strony nastąpił istotny spadek liczby urodzeń. Specjaliści ostrzegają, że ta tendencja ma się w dalszym stopniu pogłębiać, a w efekcie problemy związane z demografią będą stawały się coraz większym sprawdzianem dla polityki państw. Problematyka senioralna zahacza bowiem o wiele obszarów działalności państwa poczynając między innymi od pomocy społecznej, przez tematykę emerytalną, rynek pracy a na prawie rodzinnym i wynikających z Kodeksu Rodzinnego i Opiekuńczego ${ }^{1}$ obowiązkach alimentacyjnych kończąc. W doktrynie i literaturze przedmiotu można dostrzec spór, który odnosi się właśnie do podmiotów, które są zobowiązane do podjęcia działań pomocowych na rzecz ludzi starszych. Otóż częstą praktyką, jak zauważa Marek Andrzejewski jest „przenoszenie obowiązków ekonomicznych z rodzin na barki podatników. Sytuacja ta budzi kontrowersje - przez wielu jest akceptowana, inni zaś stanowczo twierdzą, że dochodzi w ten sposób zarówno do marnotrawienia środków, jak i do demoralizowania tych, którzy mogliby i powinni utrzymywać się samodzielnie lub też tych, którzy winni poczuwać się do obowiązku udzielania im wsparcia. Problem ma swe głębokie ekonomiczne, prawne oraz polityczne korzenie, a jego rozstrzygnięcie nie jest możliwe bez wniknięcia w spór o model polityki społecznej wobec rodziny"”.

W poniższej refleksji podejmę problem obowiązku alimentacyjnego, gdyż odnosi się on do pomocy osobom starszym poprzez działania wykonywane nie przez państwo (państwo tylko reguluje zasady tej pomocy), a rodzinę takich osób.

W pierwszej kolejności należy dookreślić pojęcie osoby starszej (seniora). Polskie prawo nie podaje jednak definicji reprezentatywnej, która określałaby kryteria, których spełnienie kwalifikowałoby takie osoby do tej grupy. Brak jest jakiejkolwiek granicy wiekowej, której spełnienie mogłoby formalnie oznaczać, że mamy do czynienia z osobą starszą. Taką granicę wiekową wprowadza natomiast

1 Ustawa z dnia 25 lutego 1964 r. Kodeks Rodzinny i Opiekuńczy (t.j. Dz.U. z 2017 r., poz. 682).

2 M. Andrzejewski, Świadczenia z pomocy społecznej a obowiązki alimentacyjne członków rodziny, „Ruch PES” 1999, nr 3/4, s. 47. 
ustawa o emeryturach i rentach z Funduszu Ubezpieczeń Społecznych ${ }^{3}$, która wyznacza wiek emerytalny dla kobiet i mężczyzn. Obecnie wynosi on 60 lat w przypadku kobiet oraz 65 lat w przypadku mężczyzn ${ }^{4}$. Należy zaznaczyć, że polski ustawodawca uzależnia przyznanie innych świadczeń również od granicy wiekowej. Tak jest w przypadku chociażby zasiłku pielęgnacyjnego wypłacanego przez urzędy właściwe dla miejsca zamieszkania świadczeniobiorcy (wójt, burmistrz lub prezydent miasta), czy też dodatku pielęgnacyjnego wypłacanego przez Zakład Ubezpieczeń Społecznych. W przypadku tego pierwszego świadczenia jednym z podmiotów uprawnionych do jego pobierania, po spełnieniu wszystkich kryteriów ustawowych, jest osoba, która ukończyła 75 lat. Podobnie jest $\mathrm{w}$ przypadku dodatku pielęgnacyjnego, w którym emeryt lub rencista, który ukończył 75 lat może po spełnieniu wszystkich wymogów liczyć na taki dodatek z urzędu. Jednak zarówno w przypadku wieku emerytalnego, jak i pozostałych wymienionych powyżej świadczeń granica wiekowa nie określa wprost, że chodzi o osoby starsze. Z kolei według Erika Eriksona, twórcy teorii rozwoju psychospołecznego, według którego człowiek przechodzi w trakcie swego rozwoju osiem stadiów - od okresu niemowlęctwa - aż do starości, starość rozpoczyna się od 65 roku życia i trwa aż do śmierci. Granice wiekową możemy przyjąć jako umowną dla dookreślenia przedziału wiekowego seniorów.

\section{Ochrona seniorów wynikająca z Kodeksu Rodzinnego i Opiekuńczego}

U podstawy regulacji obowiązku alimentacyjnego legło przekonanie o słuszności udzielania pomocy rodzicom, którzy nie są w stanie zdobyć samodzielnie niezbędnych środków utrzymania, polegającej na zabezpieczeniu ich egzystencji ${ }^{5}$. Obowiązek alimentacyjny jest bowiem, zgodnie z regułami polskiego prawa rodzinnego, podstawowym zobowiązaniem wynikającym z faktu istnienia stosunku rodzinnoprawnego. W tym kontekście należy zauważyć, że ochrona seniorów nie oznacza jedynie obowiązków ze strony ich dzieci. Istnieją zasadniczo trzy podstawowe źródła tego stosunku, tj. małżeństwo, pokrewieństwo oraz przysposobienie. Na podmiotach tych stosunków ciąży zadanie dostarczania środków utrzymania podmiotom uprawnionym w sytuacji, gdy wystąpią przesłanki do takowej pomocy. Jak wskazuje Tomasz Sokołowski „obowiązek alimentacyjny istnieje zawsze,

\footnotetext{
3 Ustawa z dnia 17 grudnia 1998 r. o emeryturach i rentach z Funduszu Ubezpieczeń Społecznych (t. j. Dz.U. z 2017 r., poz. 1321).

4 Artykuł 24 ust. 1 o emeryturach i rentach z Funduszu Ubezpieczeń Społecznych.

5 J. Winiarz, Prawo rodzinne, Warszawa 1996, s. 270.
} 
niejako potencjalnie, natomiast tylko czasem występują przesłanki prowadzące do skonkretyzowania roszczenia o alimenty"'.

Osoby starsze zostały objęte przez ustawodawcę ochroną prawną zawartą w Kodeksie Rodzinnym i Opiekuńczym i odnosi się ona przede wszystkim do obowiązku alimentacyjnego, którego mogą się domagać od swoich bliskich. Odnosząc się do kolejności alimentacji, zasadą jest, że obowiązek alimentacyjny obciąża w pierwszej kolejności najbliższą rodzinę w linii prostej, a następnie rodzinę z linii bocznej. Obowiązek alimentacyjny zobowiązanego w dalszej kolejności powstaje dopiero wtedy, gdy nie ma osoby zobowiązanej w bliższej kolejności ${ }^{7}$ oraz wówczas, gdy osoba zobowiązana w bliższej kolejności nie jest w stanie spełnić świadczenia lub gdy uzyskanie od niej na czas alimentów jest niemożliwe lub połączone $\mathrm{z}$ nadmiernymi trudnościami ${ }^{8}$. A więc obowiązek alimentacyjny względem osoby starszej w pierwszej kolejności odnosi się do zstępnych, czyli dzieci, wnuków, przed wstępnymi, czyli rodzicami, dziadkami, zaś wstępnych obciąża przed rodzeństwem ${ }^{9}$. W sytuacji, gdy uprawniony posiada kilkoro dzieci, a więc osoby, które są spokrewnione w tej samej linii i w tym samym stopniu, ciąży na nich obowiązek łożenia świadczenia alimentacyjnego na rzecz rodziców w tej samej kolejności ${ }^{10}$.

Zaznaczenia jednak wymaga, iż dopuszczalna jest taka możliwość, aby osoba starsza jako uprawniona wystąpiła do sądu z powództwem o zasądzenie alimentów od dzieci lub wnuków jedynie w sytuacji, gdy nie pozostaje w małżeństwie lub jego małżonek nie może być już takim obowiązkiem obciążony ${ }^{11}$. Okoliczność ta wynika z treści artykułu 130 Kodeksu Rodzinnego i Opiekuńczego, który stanowi, że obowiązek jednego małżonka do dostarczania środków utrzymania drugiemu małżonkowi po rozwiązaniu lub unieważnieniu małżeństwa albo po orzeczeniu separacji wyprzedza obowiązek alimentacyjny krewnych tego małżonka.

Podstawą prawną roszczenia alimentacyjnego przeciwko dzieciom jest artykuł 87 Kodeksu Rodzinnego i Opiekuńczego, zgodnie z którym rodzice i dzieci powinny się wspierać wzajemnie. Jak wskazuje Anna Sylwestrzak „obowiązek

6 T. Sokołowski, Prawo rodzinne - zarys wykładu, Wydawnictwo Ars boni et aequi 2013, s. 211.

7 Artykuł 129 § 1 Kodeksu Rodzinnego i Opiekuńczego.

8 Artykuł 132 Kodeksu Rodzinnego i Opiekuńczego.

9 A. Wilk, M. Gołowkin-Hudała, Prawne aspekty starości. Obowiązek alimentacyjny dorostego dziecka (zstępnego) wobec rodzica (wstępnego), Wydawnictwo Difin 2014, s. 135.

10 T. Smyczyński, Prawo rodzinne i opiekuńcze, Wydawnictwo C.H. Beck, Warszawa 2003, s. 696.

11 A. Wilk, M. Gołowkin-Hudała, Prawne aspekty..., s. 133. 
wspierania, dzięki swojej ogólnej treści, dopełnia pozostałe normy Kodeksu Rodzinnego i Opiekuńczego, dotyczące obowiązków wobec rodziców. Artykuł 87 Kodeksu Rodzinnego i Opiekuńczego znajduje konkretyzację w przepisach o obowiązku alimentacyjnym, w związku z tym może być powoływany obok tych przepisów, jako podstawa zasądzania alimentów. Nie może on jednak stanowić samodzielnej podstawy takiego orzeczenia, ponieważ stanowiłoby to obejście przepisów o alimentach"'12. A więc oprócz powyższego artykułu, dodatkową podstawą prawną regulującą obowiązek alimentacyjny są artykuły od 128 do 144 i artykuł 58 wraz ze zmianami wprowadzonymi mocą ustawy z dnia 6 listopada $2008 \mathrm{r}$. o zmianie ustawy - Kodeks Rodzinny i Opiekuńczy oraz niektórych innych ustaw ${ }^{13}$. Artykuł $135 \S 1$ Kodeksu Rodzinnego i Opiekuńczego, wskazuje na te przesłanki, od których uzależniony jest zakres świadczeń alimentacyjnych.

Pierwszą z nich są usprawiedliwione potrzeby uprawnionego, które są określane w sposób indywidualny przy uwzględnieniu sytuacji społecznej, wiekowej oraz zdrowotnej. Przesłanka jest związana z wystąpieniem niedostatku. Definicja niedostatku w literaturze przedmiotu funkcjonuje w węższym i szerszym znaczeniu. W „węższym” oznacza osobę, którą nie stać na zapewnienie sobie własnym staraniem egzystencji na minimalnym poziomie ${ }^{14}$. Zaś według szerszego ujęcia definicji pojęcie niedostatku należy rozumieć jako niemożność czynienia wydatków pozwalających na normalne życie na godziwym poziomie, adekwatnym do zindywidualizowanych potrzeb materialnych i niematerialnych określonej osoby $^{15}$. Sąd Najwyższy wyraził również zapatrywanie, że nie w każdym przypadku rezygnacja z możliwości uzyskania przysporzenia przez uprawnionego do alimentów, pozostającego w niedostatku, będzie prowadziła do oceny jego żądania jako bezzasadnego ${ }^{16}$. Powyższe rozważania Sądu Najwyższego sprowadzają się do sytuacji, gdy osoba odmawia świadczeń z pomocy społecznej, pomimo że taką pomoc może otrzymać. Taka dobrowolna odmowa skorzystania z pomocy społecznej w sytuacji niedostatku, przy jednoczesnym ubieganiu się o alimenty nie wyłącza możliwości ich zasądzenia, gdyż obowiązek alimentacyjny jest obowiązkiem rodziny, który powinien zostać wypełniony przed pomocą społeczną ze strony państwa. Na temat niedostatku wielokrotnie także wypowiadał się Sąd

12 A. Sylwestrzak, Obowiąki dziecka wobec rodziców, „Ruch Prawniczy, Ekonomiczny i Socjologiczny" 2001, nr 3, s. 78.

13 A. Wilk, M. Gołowkin-Hudała, Prawne aspekty..., s. 132.

14 A. Partyk, Pojęcie „niedostatku” jako podstawy obowiązu alimentacyjnego, Lex nr 206598.

15 Tamże.

16 Tamże. 
Najwyższy, który w jednym z orzeczeń wskazał, że „w niedostatku pozostaje nie taki uprawniony, który nie dysponuje żadnymi środkami utrzymania, ale także taki którego usprawiedliwione potrzeby nie są w pełni zaspokojone"17. W innym z kolei orzeczeniu, tym razem Sądu Okręgowego kwestia niedostatku również została dookreślona i w którym to orzeczeniu Sąd Okręgowy zważył, iż ,posiadanie nawet własnych środków w postaci wynagrodzenia za pracę, renty albo emerytury może pozwalać na ustalenie, że określony uprawniony znajduje się w niedostatku. Dzieje się tak wtedy, gdy wysokość osiąganych przez niego dochodów, odpowiadająca jego możliwościom zarobkowym i majątkowym nie wystarcza na pełne zaspokojenie jego usprawiedliwionych potrzeb. Przez usprawiedliwione potrzeby uprawnionego będącego w niedostatku należy rozumieć takie potrzeby, których zaspokojenie jest konieczne do godziwej egzystencji uprawnionego. Nie sposób ustalić katalogu tychże potrzeb. Należą do nich przede wszystkim potrzeby w zakresie wyżywienia, ubrania, mieszkania, ogrzewania, oświetlenia, a w razie potrzeby (...) leczenia"18.

Z kolei druga przesłanka wymieniona w artykule $135 \S 1$ Kodeksu Rodzinnego i Opiekuńczego odnosi się do majątkowych możliwości zobowiązanego, a więc dotyczy ona jego zdolności zarobkowej i sytuacji majątkowej. Na zdolność zarobkową i majątkową składają się ,nie tylko wynagrodzenie, które zobowiązany uzyskuje w ramach świadczonej pracy zarobkowej, premie, dodatki do wynagrodzenia, rentę, czy emeryturę, ale i odsetki z

akcji, akcje zgromadzone na funduszach bankowych oraz pozostałe dochody. Niepodejmowanie się lub ograniczenie bez uzasadnionych przyczyn pracy zarobkowej nie uchyla ani nie ogranicza obowiązku świadczeń" ${ }^{\prime 1}$. Warto również zauważyć, że w praktyce życiowej dość często zdarza się, że członkowie rodziny są ze sobą skonfliktowani. W konsekwencji, gdy uprawniony zwraca się z roszczeniem o alimenty, zobowiązany może umyślnie starać się wyzbyć majątku. W celu zapobieżenia takim sytuacją, ustawodawca przewidział rozwiązanie w postaci artykułu 136 Kodeksu Rodzinnego i Opiekuńczego, z którego treści wynika, że jeżeli zobowiązany w ciągu ostatnich trzech lat przed dochodzeniem świadczeń alimentacyjnych przed sądem bezzasadnie zrzekł się prawa majątkowego lub też swoim zachowaniem sprawił, że prawo majątkowe utracił, to sąd nie uwzględnia $\mathrm{w}$ takim wypadku uszczuplenia majątku jako przesłanki do zmniejszenia zakresu świadczenia alimentacyjnego. Podobnie sąd nie weźmie pod rozwagę

17 Wyrok Sądu Najwyższego z dnia 5 lipca 2000 r., sygn. akt I CKN 226/00.

18 Wyrok częściowy Sądu Okręgowego w Koninie z dnia 8 grudnia 2016 r., sygn. akt II Ca 419/16, niepublikowany.

19 S. Grzybowski, Prawo rodzinne-zarys wyktadu, Warszawa 1980, s. 232. 
zmiany zatrudnienia na mniej korzystne finansowo, czy też w ogóle zrezygnowanie $\mathrm{z}$ zatrudnienia.

Odnosząc się jeszcze do przesłanek, zawartych w artykule $135 \S 1$ Kodeksu Rodzinnego i Opiekuńczego, należy podkreślić, iż muszą one zostać spełnione kumulatywnie, aby móc skutecznie domagać się świadczenia alimentacyjnego. Dał temu wyraz Sąd Najwyższy w tezie jednego wyroku, w którym wskazał, że „brak po stronie zobowiązanego jakichkolwiek możliwości zarobkowych i majątkowych skutkuje oddaleniem powództwa o alimenty, mimo istnienia usprawiedliwionych potrzeb uprawnionego" 20 .

W sytuacji, gdy senior posiada kilkoro dzieci taki obowiązek odnosi się do każdego z dzieci, natomiast wysokość zobowiązania może się wówczas różnić, głównie z uwagi na fakt, iż w takim wypadku sąd indywidualnie ocenia możliwości zarobkowe i majątkowe podmiotów zobowiązanych do łożenia alimentów. W takim wypadku brane są pod uwagę także okoliczności, jak sytuacja życiowa i potrzeby osoby wnoszącej pozew o alimenty oraz możliwości zarobkowe i majątkowe osób pozwanych. Kolejną okolicznością, którą sąd bierze pod rozwagę to ilość osób, na których ciąży obowiązek alimentacyjny. Im więcej jest takich osób, tym proporcjonalnie obniża się wysokość takiego świadczenia na jedną osobę. Natomiast w momencie, gdy sytuacja finansowa ulegnie zmianie, czy to po stronie zobowiązanego czy uprawnionego, każda ze stron może wnieść pozew o zmianę wysokości zasądzonych alimentów. Do czynników, które usprawiedliwiają żądanie podwyższenia świadczeń należą chociażby wzrost usprawiedliwionych potrzeb osoby uprawnionej, jak również większe dochody osób, na których ciąży obowiązek alimentacyjny. Możliwa jest także sytuacja przeciwna, która może powodować obniżenie wysokości alimentów. Zgodnie z orzecznictwem Sądu Najwyższego „zmiany orzeczenia lub umowy dotyczącej obowiązku alimentacyjnego można żądać w razie zmiany stosunków (artykuł. 138 Kodeksu Rodzinnego i Opiekuńczego), przy zachowaniu reguł wynikających z artykuł 135 Kodeksu Rodzinnego i Opiekuńczego. Poprzez pojęcie „stosunków” należy rozumieć okoliczności istotne z punktu widzenia ustawowych przesłanek obowiązku alimentacyjnego i jego zakresu. Zatem zmiana stosunków to zmiana okoliczności, od których zależy istnienie i zakres obowiązku alimentacyjnego - rozumie się przez to zwiększenie usprawiedliwionych potrzeb uprawnionego lub istotne zmniejszenie możliwości zarobkowych i majątkowych zobowiązanego, które uzasadniają potrzebę skorygowania - zmniejszenia lub zwiększenia - wysokości świadczeń alimentacyjnych. Należy wziąć pod uwagę okoliczności mogące świadczyć o zmianie stosunków majątkowych stron takie jak: zmiana stosunków własnościowych powodująca utratę bądź zwiększenie majątku,

20 Wyrok Sądu Najwyższego z dnia 15 października 1998 r., sygn. Akt I CKN 860/97. 
okoliczności świadczące o zmianie możliwości zarobkowych stron, a także stan faktyczny. Zaznaczyć trzeba, że zmiana stosunków będąca podstawą do zmiany orzeczenia musi zaistnieć po uprawomocnieniu się wyroku, w którym zasądzono alimenty"21.

Podstawowym i najbardziej wydawałoby się utrwalonym w świadomości modelem ustalania prawa do alimentów jest zasądzenie sądowe, choć nie jest ono jedynym rozwiązaniem w przypadku ustalenia alimentów. Obok wspomnianego zasądzenia sądowego istnieje również możliwość niewszczynania sporu sądowego w sprawach o świadczenia alimentacyjne. Taką możliwość stwarza porozumienie, które mogą osiągnąć we własnym zakresie zobowiązany z uprawnionym seniorem. Bez potrzeby wkraczania na drogę sądową można ustalić sprawy alimentacyjne za pomocą umowy między stronami. Jednakże Kodeks Rodzinny i Opiekuńczy nie reguluje dokładnie tej problematyki. Można jednak wyprowadzić tezę, iż ustawodawca przyzwala na takie działanie na gruncie artykułu 138 Kodeksu Rodzinnego i Opiekuńczego, choć nie czyni tego w sposób bezpośredni. Przywoływany już w tekście powyższy artykuł stwierdza bowiem, że w razie zmiany stosunków strony mogą żądać zmiany orzeczenia lub umowy w sprawie alimentów.

$Z$ treści tego artykułu wynika dopuszczalność zawarcia umowy dotyczącej obowiązku alimentacyjnego, a więc należy uznać, że skoro możliwa jest sądowa zmiana umowy, to tym samym nie budzi wątpliwości dopuszczalność jej zawarcia ${ }^{22}$. Możliwość jej zawarcia rodzi za sobą wiele korzyści, często związanych z oszczędnością czasu i pieniędzy. Z kolei Tomasz Smyczyński wskazuje, że „w granicach dopuszczalnych przez ustawę umowa między stronami jest zjawiskiem korzystnym, ponieważ strony ustalają alimenty w wyniku zgody, a nie konfliktu i narzuconego rozwiązania i tym samym można spodziewać się bezkonfliktowego wykonania obowiązku"23.

Oszczędność ustawodawcy w stosunku do umownego sposobu realizacji obowiązku alimentacyjnego powoduje, że brak jest również sprecyzowania formy, w jakiej umowa ta powinna zostać zawarta. Wobec tego należy przyjąć, że każda forma jest dopuszczalna, łącznie z ustną, choć może być ona problematyczna pod kątem dowodowym, w sytuacji hipotetycznego postępowania sądowego. Dlatego korzystniejszą z punktu widzenia dowodowego jest umowa w formie pisemnej, która powinna zawierać datę i miejsce jej zawarcia, oznaczenie stron umowy,

21 Wyrok Sądu Najwyższego z dnia 25 maja 1999 r. sygn. akt I CKN 274/99.

22 G. Jędrejek, Komentarz aktualizowany do artykułu 138 Kodeksu rodzinnego i opiekuńczego, Lex dostęp: 25.01.2018 r.

23 T. Smyczyński, Prawo rodzinne i opiekuńcze, Analiza i wykładnia, Warszawa 2001, s. 399. 
wysokość alimentów, częstotliwość i termin uiszczania, sposób oraz własnoręczne podpisy stron. Najkorzystniejszą formą jednak wydaje się umowa sporządzona w formie aktu notarialnego, która dodatkowo powinna zawierać jeszcze klauzulę dotyczącą poddaniu się egzekucji z aktu notarialnego. Kwestię tą reguluje artykuł $777 \S 1$ pkt 4 Kodeksu postępowania cywilnego, który wskazuje, że tytułem egzekucyjnym może być akt notarialny, w którym zobowiązany poddał się egzekucji, co oznacza obowiązek zapłaty określonej sumy pieniężnej ${ }^{24}$. Z kolei w uchwale z dnia 4 grudnia 2013 r. Sąd Najwyższy, odnosząc się do zagadnienia prawnego, „Czy jest dopuszczalne nadanie klauzuli wykonalności aktowi notarialnemu, w którym dłużnik złożył oświadczenie o poddaniu się w trybie artykułu 777 § $1 \mathrm{pkt}$ 4 Kodeksu postępowania cywilnego egzekucji co do świadczeń alimentacyjnych, wypowiedział się w tej kwestii twierdząco, wskazując, że jedynie w sytuacji, gdy z treści aktu notarialnego lub oświadczenia dłużnika o poddaniu się egzekucji wynika w sposób oczywisty, że zostało złożone w celu obejścia prawa sąd może oddalić wniosek o nadanie takiemu aktowi notarialnemu klauzuli wykonalności.

Uprawniony, który zawarł umowę ze swoimi bliskimi w formie aktu notarialnego posiada tytuł egzekucyjny, a w przypadku, gdy treść umowy wynikająca $z$ aktu notarialnego nie zostanie wykonana, może zwrócić się do sądu o nadanie klauzuli wykonalności takiemu tytułowi egzekucyjnemu, który jednocześnie staje się tytułem wykonawczym. A w tej sytuacji, jeśli senior nie otrzymuje świadczenia alimentacyjnego na jego rzecz, może zostać wszczęta egzekucja komornicza.

\section{Okoliczności wylączające możliwość ubiegania się przez seniora o świadczenie alimentacyjne}

Kodeks Rodzinny i Opiekuńczy przewiduje pewne ograniczenia, co do możliwości ubiegania się przez uprawnionego o alimenty. Ustawodawca w artykule 144 Kodeksu Rodzinnego i Opiekuńczego ${ }^{25}$ wymienia okoliczność, na którą może się powołać zobowiązany, aby skutecznie uwolnić się od płacenia alimentów. Taką

24 Tytułami egzekucyjnymi są:

4) akt notarialny, w którym dłużnik poddał się egzekucji i który obejmuje obowiązek zapłaty sumy pieniężnej lub wydania rzeczy oznaczonych co do gatunku, ilościowo w akcie określonych, albo też wydania rzeczy indywidualnie oznaczonej, gdy w akcie wskazano termin wykonania obowiązku lub zdarzenie, od którego uzależnione jest wykonanie.

25 Artykuł 144 Kodeksu Rodzinnego i Opiekuńczego: Zobowiązany może uchylić się od wykonania obowiązku alimentacyjnego względem uprawnionego, jeżeli żądanie alimentów jest sprzeczne z zasadami współżycia społecznego. Nie dotyczy to obowiązku rodziców względem ich małoletniego dziecka. 
okolicznością są zasady współżycia społecznego i jest ona podstawą do uchylenia się od świadczenia alimentacyjnego. Jak wskazał Sąd Najwyższy w uchwale z dnia z 16 grudnia 1987 r. ${ }^{26}$ wypadki rażącego naruszenia przez osobę uprawnioną zasad życia w rodzinie uzasadniające oddalenie powództwa o zasądzenie alimentów mogą występować zarówno w razie istnienia obowiązku alimentacyjnego między krewnymi (artykuł 133 § 1 i 2 Kodeksu Rodzinnego i Opiekuńczego), jak i przy alimentacji małżonka w czasie trwania małżeństwa i po jego ustaniu (artykuł 27 i 60 Kodeksu Rodzinnego i Opiekuńczego). Przykładowego wyliczenia przypadków rażącego naruszenia dokonał Tomasz Smyczyński, który zaliczył do nich między innymi zachowania godzące w życie i zdrowie członka rodziny, zachowania naruszające godność, dobre imię i inne dobra osobiste człowieka, czy też zawinione popadnięcie w niedostatek lub umyślne wywołanie sytuacji prowadzącej do żądania alimentów ${ }^{27}$. W kontekście osób starszych, ten zapis w Kodeksie Rodzinnym i Opiekuńczym może powodować, że występowanie z roszczeniem alimentacyjnym przez seniora uprawnionego do alimentacji, który w przeszłości nie interesował się wychowaniem, nie wywiązywał się ze swoich obowiązków rodzicielskich, czy w przypadkach, gdy doszło do pozbawienia władzy rodzicielskiej uznane zostanie jako poważna niesprawiedliwość. Zatem wprowadzenie takiego legislacyjnego zapisu powoduje troskę o poczucie sprawiedliwości względem osoby, na której ciąży obowiązek alimentacyjny. Jednak mimo wszystko doszukać się można pewnych rozbieżności interpretacyjnych, które mogą się pojawić w sytuacji, gdy na przykład rodzic, który w przeszłości zaniedbywał swoje obowiązki rodzicielskie, a na starość popada nie ze swojej winy w niedostatek przy okazji nie posiadając żadnych możliwości zarobkowych lub majątkowych. W tym wypadku uzasadnionym wydaje się przeanalizowanie przez sąd, wobec której z osób należy zasady współżycia społecznego zastosować. Czy w przypadku dorosłego już dziecka czy rodzica, który znalazł się w kryzysowej sytuacji. Czy w tej sytuacji należy wziąć pod uwagę naganne zachowanie rodzica z przeszłości względem dziecka, czy też wziąć pod uwagę jego trudną sytuację życiową i usprawiedliwione potrzeby uprawnionego ${ }^{28}$. Zasady współżycia społecznego jako klauzula generalna została uregulowana w artykule 5 Kodeksu Cywilnego ${ }^{29}$. Nie jest bowiem możliwe

26 Uchwała Sądu Najwyższego z dnia 16 grudnia 1987 r., sygn. akt III CZP 91/86, LexisNexis nr 304360, OSNCP 1988, nr 4, poz. 42.

27 T. Smyczyński, Roszczenia alimentacyjne a zasady współżycia społecznego, „Studia Prawnicze" 1983, nr 1., s. 86 i następne.

28 A. Wilk, M. Gołowkin-Hudała, Prawne aspekty..., s. 145.

29 Artykuł 5 Kodeksu Cywilnego: „Nie można czynić ze swego prawa użytku, który by był sprzeczny ze społeczno-gospodarczym przeznaczeniem tego prawa lub z zasadami 
przytoczenie katalogu zamkniętego zachowań i życiowych sytuacji, które mogłyby zostać wpisane w tą definicję. Klauzula generalna zasad współżycia społecznego ma przede wszystkim być dopasowana do realiów życia codziennego. Może się zdarzyć, że uprawniony senior spełnił wszystkie przesłanki do tego, aby uzyskać alimenty, natomiast przywołując zasady współżycia społecznego sąd nie orzekanie o zasadności obowiązku alimentacyjnego. Również w przypadku naruszenia zasad współżycia społecznego sąd ma możliwość, w przypadku, gdy taki obowiązek alimentacyjny już jest wykonywany, a uprawniony przez swoje zachowanie nadużywa tego prawa taki obowiązek uchylić.

Omówienie powyższej problematyki w kontekście relacji pomiędzy alimentami a zasadami współżycia społecznego, można dokonać zaczynając od analizy przykładowego orzeczenia sądowego wydanego przez Sąd Okręgowy w Słupsku ${ }^{30}$. Sprawa dotyczyła roszczenia alimentacyjnego, z którym powódka wystąpiła wobec pozwanych synów. W pozwie wskazywała, że jest osobą schorowaną, po przebytym udarze mózgu, porusza się przy pomocy balkonika. Dodatkowo utrzymuje się z emerytury, która nie wystarcza na pokrycie podstawowych kosztów utrzymania, natomiast pozwani synowie nie interesują się nią i nie pomagają finansowo, choć posiadają ku temu możliwości. Synowie z kolei wnieśli o oddalenie powództwa, podnosząc, że ich matka jest osobą uzależnioną od alkoholu, nienależycie wypełniała swój obowiązek alimentacyjny wobec pozwanych w okresie ich małoletniości, co w konsekwencji skutkowało brakiem zabezpieczenia podstawowych potrzeb małoletnich synów, którzy nie mieli warunków do nauki, a dodatkowo w wieku kilkunastu lat zmuszeni byli do podejmowania dorywczych prac, aby zakupić odzież oraz podręczniki szkolne. Dopiero, gdy ich ojciec przejął nad nimi pieczę sytuacja wróciła do normalności.

W przedmiotowym orzeczeniu sądy obu instancji oddaliły żądanie powódki. Przede wszystkim podniosły, iż powódka nie znajduje się w niedostatku oraz, że żądanie powódki jest sprzeczne z zasadami współżycia społecznego. W uzasadnieniu, Sąd Okręgowy w Słupsku wskazał, że nawet gdyby przyjąć, że sytuacja materialna, w której znalazła się powódka pozwala na stwierdzenie, że znajduje się $w$ niedostatku, to $i$ tak powództwo to nie zasługiwało na uwzględnienie, gdyż ze względu na obowiązujący przepis artykułu $144^{1}$ Kodeksu postępowania rodzinnego, który stanowi podstawę w przypadku zobowiązanego, w określonych przypadkach, do uchylenia się od wykonywania obowiązku alimentacyjnego. Sąd Okręgowy stwierdził, że: „Powódka jako matka nie wykonywała swych

współżycia społecznego. Takie działanie lub zaniechanie uprawnionego nie jest uważane za wykonywanie prawa i nie korzysta z ochrony".

30 Wyrok Sądu Okręgowego w Słupsku z dnia 7 lutego 2014 r., sygn. akt IV Ca 34/14. 
obowiązków rodzicielskich w należyty sposób, nie interesowała się życiem synów, nie dbała o właściwe wprowadzenie ich w dorosłość. To sami pozwani jeszcze przed uzyskaniem pełnoletności musieli troszczyć się o swoje utrzymanie, o przygotowanie posiłków, o edukację. Powódka doprowadzała wręcz do sytuacji, że będąc pod wpływem alkoholu stwarzała zagrożenie życia pozwanych - rzucając w nich różnymi przedmiotami, w tym również nożem. Synowie wstydzili się matki, wstydzili się także mieszkania, w którym mieszkali, bo czuć w nim było alkohol. Powódka nie interesowała się losem dzieci, nie dbała o ich przyszłość. Wszystko to, co pozwani osiągnęli w życiu, osiągnęli dzięki własnej pracy i samozaparciu oraz pomocy osób trzecich - nie matki”’31.

Sąd Okręgowy w przytoczonym orzeczeniu wyraził pogląd, który rozstrzygnął powyższy spór w relacji pomiędzy obowiązkiem alimentacyjnym a zasadami współżycia społecznego. Pomimo, że osoba uprawniona do alimentów oraz zobowiązani mogli wypełniać warunki zawarte w artykule 135. § 1, a więc jak w przytoczonym orzeczeniu po stronie uprawnionego nawet gdyby przyjąć, że matka znalazła się w niedostatku, zaś po stronie zobowiązanych istniały zarobkowe i majątkowe możliwości, które de facto posiadali, sąd mógł nie nałożyć na zobowiązanych obowiązku alimentacji, powołując się na zasady współżycia społecznego. Należy zauważyć, że wszystkie sprawy, które są przedmiotem postępowania sądowego oceniane są przez sąd indywidualnie. Sąd w każdym przypadku bierze pod rozwagę konkretny stan faktyczny, badając zasadność zasądzenia świadczenia alimentacyjnego między innymi pod kątem artykułu 5 Kodeksu cywilnego i artykułu $144^{1}$ Kodeksu Rodzinnego i Opiekuńczego. W sporze doktrynalnym ten ostatni przepis ustawodawcy jest uznawany za podsumowanie długotrwałego sporu co do kwestii możliwości powoływania się na zasady współżycia społecznego w sprawach związanych z dochodzeniem roszczeń alimentacyjnych ${ }^{32}$. Jak podkreśla Aleksandra Wilk regulacji tej nie należy „,postrzegać jako formy odwzajemnienia negatywnych doświadczeń z przeszłości między zobowiązanym a uprawnionym. W przypadku zasądzenia alimentów od dziecka na rzecz rodzica, sprzeczność z zasadami współżycia społecznego mogłaby mieć co prawda miejsce wówczas, gdy stopień udziału rodzica w wychowaniu i utrzymaniu dziecka był niewystarczający, gdy w odczuciu dziecka, obciążenie go obowiązkiem alimentacyjnym mogłoby być niesprawiedliwe. Nie jest jednak uzasadnione kierowanie się $\mathrm{w}$ tej ocenie jakimkolwiek rozliczaniem stopnia udziału w zaspokajaniu potrzeb

\footnotetext{
31 Tamże.

32 T. Sokołowski, Komentarz do artykułu 1441 Kodeksu Rodzinnego i Opiekuńczego, w: Kodeks rodzinny i opiekuńczy, red. H. Dolecki, T. Sokołowski, LEX a Wolters Kluwer business, Warszawa 2013, s. 949.
} 
dziecka w przeszłości i przeliczaniem go na wysokość obowiązku alimentacyjnego w późniejszym czasie wobec rodzica"33.

Możliwa jest także sytuacja, gdy alimenty zostały już zasądzone przez sąd, a w czasie realizowania tego obowiązku przez zobowiązanego doszło do zmiany stosunków między tymi podmiotami, które stanowią podstawę do stwierdzenia bezzasadności świadczenia alimentacyjnego, a więc sytuacji, w której doszło do naruszenia zasad współżycia społecznego. W takim wypadku zobowiązany posiada możliwość złożenia wniosku do sądu o uchylenie obowiązku alimentacyjnego. A zatem należy przed sądem udowodnić, że alimenty w stosunku do uprawnionego są niezgodne z zasadami współżycia społecznego.

\section{Zakończenie}

Analiza orzecznictwa oraz przepisów zawartych Kodeksie Rodzinnym i Opiekuńczym odnoszących się do obowiązków alimentacyjnych pozwala stwierdzić, że dotyczy swoim zasięgiem także osoby starsze. Regulacje zawarte w Kodeksie Rodzinnym i Opiekuńczym nie budzą wątpliwości, gdyż taka pomoc w ramach rodzinnoprawnego stosunku wynika z obowiązku wzajemnej pomocy rodziców i dzieci oraz przepisów dotyczących obowiązków alimentacyjnych, dla których ustawodawca przewidział miejsce w Dziale III Kodeksu Rodzinnego i Opiekuńczego. Choć w niektórych przypadkach może zostać ona ograniczona $\mathrm{z}$ uwagi na naganne zachowanie uprawnionego, który oczekuje pomocy w formie alimentów. Taka sytuacja ma miejsce w sytuacji, gdy zobowiązany udowodni, że obowiązek alimentacyjny jest sprzeczny z zasadami współżycia społecznego. Jednakże określenie zasad współżycia społecznego jest zwrotem niedookreślonym i może mieć różnorakie znaczenie. Dlatego w sytuacji procesu sądowego sąd bada stan faktyczny pod kątem konkretnej sprawy, choć zgodnie z utrwalonym w tej materii orzecznictwem sądowym oraz literaturą przedmiotu możemy do takich rażących zachowań zakwalifikować szereg przypadków, chociażby naruszanie godności osobistej osoby zobowiązanej do obowiązku alimentacyjnego, dopuszczenie się przestępstwa przeciwko takiej osobie, czy chociażby trwonienie pieniędzy uzyskanych z tytułu alimentów na cele nie związane ze swoimi usprawiedliwionymi potrzebami. W takich wypadkach, zgodnie z ogólną regułą dowodową - zgodnie, z którą ciężar dowodu spoczywa na osobie, która z danego faktu wywodzi skutki prawne ${ }^{34}$, strona dochodząca świadczeń alimentacyjnych musi te fakty wykazać.

33 A. Wilk, M. Gołowkin-Hudała, Prawne aspekty..., s. 145.

34 Artykuł 6 Kodeksu Cywilnego: Ciężar udowodnienia faktu spoczywa na osobie, która $\mathrm{z}$ faktu tego wywodzi skutki prawne. 


\section{Bibliografia}

Andrzejewski M., Świadczenia z pomocy społecznej a obowiązki alimentacyjne członków rodziny, „Ruch PES” 1999, nr 3/4, s. 47.

Grzybowski S., Prawo rodzinne - zarys wyktadu, Warszawa 1980, s. 232.

Jędrejek G., Komentarz aktualizowany do art.138 Kodeksu rodzinnego i opiekuńczego, Lex dostęp: 25 stycznia $2018 \mathrm{r}$.

Partyk A., Pojęcie ,niedostatku” jako podstawy obowiazku alimentacyjnego, Lex nr 206598.

Smyczyński T., Prawo rodzinne i opiekuńcze, wyd. C.H. Beck, Warszawa 2003, s. 696.

Smyczyński T., Prawo rodzinne i opiekuńcze, Analiza i wyktadnia, Warszawa 2001, s. 399.

Smyczyński T., Roszczenia alimentacyjne a zasady współżycia społecznego, „Studia Prawnicze” 1983, nr 1, s. 86 i następne.

Sokołowski T., Prawo rodzinne-zarys wyktadu, wyd. Ars boni et aequi 2013, s. 211.

Sokołowski T., Komentarz do artykułu 1441 Kodeksu Rodzinnego i Opiekuńczego, w: Kodeks rodzinny i opiekuńczy, red. H. Dolecki, T. Sokołowski, LEX a Wolters Kluwer business, Warszawa 2013, s. 949.

Sylwestrzak A., Obowiazki dziecka wobec rodziców, „Ruch Prawniczy, Ekonomiczny i Socjologiczny" 2001, nr 3, s. 78.

Uchwała Sądu Najwyższego z dnia 16 grudnia 1987 r., sygn. Akt III CZP 91/86, LexisNexis $\mathrm{nr} 304360$.

Ustawa z dnia 25 lutego 1964 r. Kodeks Rodzinny i Opiekuńczy (t.j. Dz.U. z 2017 r., poz. 682).

Ustawa z dnia 17 grudnia 1998 r. o emeryturach i rentach z Funduszu Ubezpieczeń Społecznych (t. j. Dz.U. z 2017 r., poz. 1321).

Wilk A., Gołowkin-Hudała M., Prawne aspekty starości. Obowiazek dorostego dziecka (zstępnego) wobec rodzica (wstępnego), wyd. Difin 2014, s. 135.

Winiarz J., Prawo rodzinne, Warszawa 1996, s. 270.

Wyrok Sądu Najwyższego z dnia 5 lipca 2000 r., sygn. akt I CKN 226/00.

Wyrok częściowy Sądu Okręgowego w Koninie z dnia 8 grudnia 2016 r., sygn. akt II Ca 419/16, niepublikowany.

Wyrok Sądu Najwyższego z dnia 15 października 1998 r., sygn.. akt I CKN 860/97. Wyrok Sądu Najwyższego z dnia 25 maja 1999 r., sygn. akt I CKN 274/99.

Wyrok Sądu Okręgowego w Słupsku z dnia 7 lutego 2014 r., sygn. akt IV Ca 34/14. 


\title{
Piotr Czekalski: Maintenance law for seniors on the ground of the Family and Guardianship Code and judicial decisions
}

\begin{abstract}
Summary
Due to the fact that the issues related to the problem of the aging societies are increasingly present in the public discourse, questions about older people arise. Although they are asked fall in various contexts, it should undeniably be recognized that seniors often need material help due to their advanced age or health problems. It is true that the country has at its disposal appropriate aid instruments, which are addressed to such a group of recipients, but it should be emphasized that the family maintenance obligation should be implemented in the first place. That is why the issue of alimony obligations towards older people has been taken up in this text, as it focuses on the obligations arising from family ties. The analysis of the issue has been discussed on the example of common courts and Supreme Court judgments, as well as on the basis of the provisions of the Family and Guardianship Code.
\end{abstract}

Keywords: senior, elderly person, alimony, maintenance obligation, Family and Guardianship Code, case law. 